\title{
AN ANALYSIS OF STUDENTS' WRITING SKILL IN DESCRIPTIVE TEXT AT GRADE X1 IPA 1 OF MAN 2 PADANG
}

\author{
LAILATUL HUSNA \\ Volume 1 Nomor 1 \\ JIPS ISSN: 2579-5449
}

\begin{abstract}
This research was a descriptive research with the main aim to analyze the students' descriptive text quality in English subject. The components that were analized analyzed in the descriptive text written by the students were developing ideas, organizing ideas, grammar, vocabulary and mechanics. These five components were analyzed based on the five categories, they are excellent, good, satisfactory, weak and poor. The participants of this research were 30 students in their second year of MAN 2 Padang. The topic was about places, in which the students chose the place that they want to describe. The technique used to get the participants of the reserach was cluster random sampling technique. The data of the research were taken by using writing test.

In this research it was found that the students faced some difficulties in organizing ideas and developing ideas. Some of the students were unable to develop the ideas well. It was also found in their second writing, there were no improvements on the developing ideas.

Furthermore, the students were unable to identify and describe the objects in organizing ideas components. In the grammar components, the students did not find major difficulties because the tense was simple present tense which was expressed only in simple sentences. For the vocabulary component, it was found that few students were unable to use the appropriate words to describe the place and they used some Indonesian words too. For the mechanics component, the students did not find major difficulties in using the appropriate mechanics.

Based on the result of the research, the students are suggested to pay attention to the whole components of the descriptive text especially in developing and organizing ideas components. It is suggested to the teacher of MAN 2 Padang to use an effective strategy and give various ways to develops students' ideas. The teacher should help the students to brainstorm the ideas or make an outline of their writing, to help the students to organize and develop their ideas well.
\end{abstract}

Key Word: students' ability, descriptive writing

\section{ABSTRAK}

Penelitian ini terdiri dari masalah, tujuan penelitian, metoda, temuan penelitian dan kesimpulan. Penelitian ini terfokus kepada kemampuan siswa dalam menulis teks deskriptif. Teks deskriptif termsuk kedalam jenis teks yang tidak terlalu sulit namun masih ditemukan beberapa kesulitan yang dihadapi siswa saat menulis karangan ini, fenomena inilah yang melatar belakangi peneliti ingin melakukan penelitian ini. Tujuan dari penelitian ini adalah untuk menganalisa kemampuan siswa dalam menulis teks deskriptif. Dalam mengumpulkan data, peneliti menggunakan tes menulis sebagai instumen dalam menganalisa tulisan siswa. Penelitian ini merupakan sebuah penelitian descriptive quantitative yang bertujuan untuk 
menganalisis kualitas siswa dalam menulis teks deskriptif. Komponen-komponen yang dianalisis dalam teks deskriptif yang ditulis adalah struktur-struktur umum dalam menulis teks deskriptif itu sendiri, komponennya adalah pengembangan ide, pengorganisiran ide, tata bahasa, kosa kata dan tanda baca. Peneliti menganalisis kemampuan menulis siswa berdasarkan lima kategori: sangat bagus, bagus, cukup, lemah, kurang dan sangat kurang. Berdasarkan lima kategori ini maka dianalisislah hasil tes menulis deskriptif siswa berdasarkan rubrik skor yang digunakan. Topik yang ditulis siswa merupakan topik tentang tempat/place. Mereka dapat memilih "tempat" mana saja yang mereka inginkan. Penelitian ini dilakukan di MAN 2 Padang kelas XI IPA1. Hasil penelitian ini menggambarkan bahwa siswa menghadapi kesulitan dalam mengorganisir ide dan mengembangkan ide. Mereka tidak mampu mengembangkan ide pada teks yg mereka tulis.
Sedangkan pada komponen grammar tidak dinemukan kesulitan karena teks deskriptif secara umum menggunakan kalimat-kalimat sederhana. Pada komponen kosa kata juga masih ditemukan beberapa kesulitan oleh beberapa orang siswa dalam mengaplikasikan kosa kata bahasa inggris yang baik, bahkan diantara mereka masih ada yang menggunakan bahasa Indonesia. Untuk komponen tanda baca juga tidak ditemukan kesalahan yang begitu berarti. Berdasarkan hasil penelitian ini guru disarankan untuk lebih memperhatikan pengajaran struktur teks deskriptif dalam pengembangan ide, pengaturan ide, grammar, kosa kata san mekanik. Guru juga diharapkan lebih banyak memberikan contoh dan latihan mengenai deskriptif teks kepada siswa sehingga tercapai tujuan pendidikan dengan baik, khususnya mata pelajaran baahsa inggris. Guru dapat melakukan brainstorming dan outlining sebelum menulis sebuah teks berbahasa Inggris.

\section{Kata Kunci: kemampuan menulis, karangan deskriptif}

\section{INTRODUCTION}

Writing is usually regarded as the most difficult skill to learn, not only because of the needs to master many skills of English; reading, speaking, vocabulary, grammar and etc, but also because of the difference between the learners' native language rules and that of the language being learned. In expressing idea one should consider many aspects that will support writing, such as, the relationship between topic, idea and context, correct grammar, good spelling, mechanics, and vocabulary. Based on the Senior High School Competency Based Curriculum, the students are expected to be able to communicate in English both in oral and written form. In senior high school in Indonesia, the skill of writing is taught by using genre based approach. Students are introduced to some genres and taught through the model of reading texts where they are explicitly taught about the social function, the generic structures, and the language features of the genres. By introducing them to the reading model texts, they are expected to know and understand the difference between one genre to another in English, so that they are able to write the genres by themselves with the right order of generic structures and the correct use of the language features of genres.
There are twelve genres that are taught to senior high school students. Those are descriptive, recount, narrative, procedure, explanation, discussion, exposition, news item, Information report, annecdote and review. Researcher focused on descriptive text which is taught to them in their second year. As stated above, descriptive text is taught by introducing the students to the model text with a hope that they will be able to write the genre well.

A descriptive text is a text by which a writer tries to picture what he is describing. Description is used to describe a particular thing/object, place, or person. In this research, the students wrote a place. For example; Where is the place?, How big is it? How cold or warm is the place?, How does the place make you feel? why?, What things can you see in this place? etc. For example, when a student wants to describe about his house, so, he should have background knowledge about parts of his house.

From the explanation above, the researcher interested to analyze and focus on students' difficulties in writing descriptive text such as developing their ideas, organizing ideas, grammar, mechanics and using vocabulary appropriately. There are two generic structures of 
descriptive writing: identification and description. Identification is a part of text where the students could identify the phenomenon and description was the part where the students are able to describe parts, qualities and characteristics.

In writing a descriptive text, students often found some difficulties although they have been guided by their teachers to write it. There are some difficulties that students face during writing the descriptive paragraph: first, the problem in developing the ideas. Some students write many main ideas in one paragraph; the idea of the paragraph is still ambiguous. Sometimes, it is also found that some paragraphs are written in one sentence only. The idea of the paragraph was still not clear. Second, the problem in organizing the ideas to write a descriptive text. A paragraph needs more than a unified point; it needs a reasonable organization or sequence. The students have to organize their ideas into good paragraphs; the students have to make their writing readable. Organizing a paragraph is the same as organizing an essay. To write a descriptive paragraph, the students can organize their ideas by identifying the topic and give the descriptions about the topic. Third, the students found difficulties in grammar. Grammar difficulties will influence certain patterns of how words are put together to form the correct sentences. It will make the ideas do develop well. Fourth, when students proceed writing something, many problems could be found. Some students are lack of vocabularies and they also have difficulties in developing their ideas related to their topic. Some students are still in doubt with choosing the correct words while composing descriptive text. Lack of vocabularies made student confused in developing their ideas. In this case the students have to choose correct words that they need. Fifth, students' difficulties on spelling, punctuation and capitalization. Based on this phenomenon, it can be concluded that students make some mistakes in mechanic aspect. Spelling, punctuation and capitalization difficulties can also affect the meaning of the sentences in a paragraph; they make the reader confused on the contiguity meaning of the sentences even of the paragraph. Unfortunately, many students are not interested in writing about something, even though it is about their life. They prefer reading and speaking to writing. As stated before, writing is more difficult than others since it needs more aspects. It involves many different elements such as grammar, vocabulary, organization of ideas, spelling, and punctuation marks.

Writing becomes the most difficult skill when it is learned by the foreign language learners. "Writing is a difficult skill for native speakers and non-native speakers; because writers must be able write it in multiple issues such as content, organization, purpose, audience, vocabularies and mechanics such as punctuation, spelling, and capitalization" (Rass, 2001:30). According to Brown (2001): "writing is thinking process, because writing is a process of putting ideas down on paper to transform thought into words and give them structure and coherent organization". Hugley et al (1983:3) explain that "writing is a communicative act. It depends upon the awareness of the social expectation". This means as communicative act, writing can develop social relationship and social expectation because writing is one of the tools of communication.

Furthermore, writing is an essential aspect of interaction on language teaching beside reading and speaking. The students learn it, because it can be used to practice grammatical rules. Harris (1997:38) states that "the students can use writing to express their ideas, opinions, realities, and point of view. People can communicate a variety of messages known readers or unknown readers by writing. Such communication is extremely important in the modern world, whether the interaction takes the form of most technologically advanced electronic mail". In conclusion, writing is as a communicative activity needs to be encourages nurtured during the language learners' course of study.

Myles (2002:1) notes that "the ability to write well is not a naturally acquired skill; it is usually learned or culturally transmitted as a set of practices in formal instructional settings or other environments. Writing skills must be practiced and learned trough experience".

Based on the ideas above, the researcher concludes that writing is a thinking process, a transaction with words followed by a physical act. It requires practice to communicate and make contacts from the writer to the reader. In this writing activity the writer follows the rules of grammar, spelling, punctuation and sentence structure.

Knapp and Watkins (2005:95) state "the genres of describing are one of the fundamental functions of any language system and one of the first skills emergent language users learn to 
control". They also state that "descriptions enable the categorisation or classification of an almost infinite range of experiences, observations and interaction into a system that orders them either objectively or subjectively, depending on the learning areaor intent of the writer".

Based on the national curriculum KTSP (School Based Curriculum) 2006, the aim teaching writing at senior high school is that the students are able to write a simple descriptive text. The skill to write descriptive text is taught at the first year. Sudarwati and Eudia (2007:113137) state that "the targets of teaching writing descriptive text for the first year students of senior high school are (1) the students are able to describe animals and people, (2) the students are able to describe their school, (3) the students are able to describe places".

They also propose the characteristics of a descriptive text such as: first, Using specific words to state the controlling the idea; second, limiting the description of a place in terms of time of day and season of the year. Get the subject into focus before starting describing. Third, choose the word carefully; using the words and phrase that convey sharp descriptive images with many kinds of words, not just adjectives; fourth, describing a person not by simply compiling a list of his or her physical appearances; clarifying the central impression of the reason and then developing the central impression with clear descriptive details. Fifth, do not really just a few descriptive details to convey the central impression. Sixth, do not be confused of objective description with subject description. In objective description, the object being described becomes more important than perception of the object.

Descriptive text usually have own specific features as follows: first, make use of adjectives and adverbs. Second, Use comparison to help picture it-something is like something. Third, Employ students' five sense- how it feels, smells, looks, sounds and tastes. (Taken from Modul Bahasa Inggris 2008).

Descriptive text is very much different from the other kinds of text. Descriptive text is the text that describes something. Wyrick (1987:227) states, "The writer of description creates a word-picture of persons, places, objects, and emotions using a careful selection of detail to make an impression on the reader." From the explanation above it can be concluded that descriptive writing is a kind of writing that consists of description, characteristics, definition of something, object or person. Then, this descriptive text is usually in simple present tense. It is necessary for the teacher to make teaching and learning writing descriptive text more interesting.

Based on the definitions above, it can be concluded that descriptive text is the text that describes something in order the readers or listeners are able to get the same sense as what the writer experienced with his/her six senses: looks, smells, feels, acts, tastes, and sounds. It helps another to understand your experience.

The description of place is bringing the student into the situation where they have been there. According to Knapp and Watkins (2005) "a description of place can include physical and emotional description. A description of place sometimes includes descriptions of objects and/or people that may be associated with the place". It means that by giving complete information about the place it more interesting by including details that express feelings about this special place. Furthermore, researcher gives them some questions to help the students to write effectively, such as; what do you think about the place? How is the interior and exterior design? What did you like about it, etc.

The generic structure of the descriptive text is different from other texts. There are two main components in the generic structure of descriptive text. They are identification and description. Gerot and Peter (1994:208) mention that "there are two components in the descriptive text: first, identification; identifies phenomenon to be described, and description; describes parts, qualities, and characteristics". The identification usually occurs in the first paragraph and the description stated in the continuing paragraph. The description consists of three parts: the parts of the place, the quality of the place and the characteristic of the place.

Sudarwati and Eudia (2005:27) mention that "there are two components of the generic structure of descriptive text. They are identification; identify phenomenon to be described and description; describes parts, qualities, and characteristics". They add that "the language features for descriptive text are focus on specific participants, use of attributive and identifying process, frequently use classifiers in nominal groups, and use of Simple present tense".

Good organization helps the reader better understand the ideas presented. The descriptive 
writing is organized according to how the person, place, or object exists in the real world. For example, a description of house might begin with the outside, then move to the inside, and proceed from room to room. Knapp and Watkins (2005: 80) said that "organizing writing according to parts of the whole helps a reader to better visualize the items being described".

The components of writing descriptive are developing ideas, organizing ideas, grammar, vocabulary and mechanics. For detail, it can be seen on the following table:

Table 1

Indicators of Descriptive text

\begin{tabular}{|c|c|c|}
\hline The Content & Indicator & Sub-Indicator \\
\hline $\begin{array}{l}\text { 1. Developing } \\
\text { Ideas }\end{array}$ & $\begin{array}{l}\text { 1. Paragraph Unity } \\
\text { 2. Coherence }\end{array}$ & $\begin{array}{l}\text { a. topic } \\
\text { b. topic sentence } \\
\text { c. supporting sentence } \\
\text { d. concluding sentence } \\
\text { a. the sentence hold together } \\
\text { b. understandable }\end{array}$ \\
\hline $\begin{array}{l}\text { 2. Organizing } \\
\text { Ideas }\end{array}$ & 3. Description & $\begin{array}{l}\text { a. repeat key words from sentence } \\
\text { to sentence } \\
\text { b. use pronoun for preceding key } \\
\text { term } \\
\text { c. use demonstrative adjective } \\
\text { use connecting words } \\
\text { a. identify the name of place and } \\
\text { location } \\
\text { b. describe the complete features of } \\
\text { the place } \\
\text { Parts, Qualities and Characteristics }\end{array}$ \\
\hline 3. Grammar & $\begin{array}{l}\text { 1. Simple Present tense } \\
\text { 2.Relational verbs }\end{array}$ & $\begin{array}{l}\text { a. to describe actions or conditions } \\
\text { that are usual, habitual or } \\
\text { permanent } \\
\text { b. to state general / truth } \\
\text { c. for future action on schedule } \\
\text { time } \\
\text { d. for future action in certain time } \\
\text { relational verbs used when } \\
\text { classifying and describing } \\
\text { appereances/qualities and } \\
\text { parts/functions of phenomena (is, } \\
\text { are, has, have) } \\
\text { used to add extra informtion to } \\
\text { nouns and may be technical, } \\
\text { everyday or literally, depending on } \\
\text { the text. }\end{array}$ \\
\hline 4. Vocabulary & 1. Word choices & $\begin{array}{l}\text { Choose the appropriate and } \\
\text { accurate words to express ideas. }\end{array}$ \\
\hline
\end{tabular}




\begin{tabular}{|l|l|l|}
\hline 5. Mechanics & 2. Amount of Vocabulary & 200 words \\
\hline 2. Cunctuation & $\begin{array}{l}\text { a. comma } \\
\text { b. Period } \\
\text { c. the colon } \\
\text { d. semicolon } \\
\text { e. apostrophe } \\
\text { f. Quotation marks } \\
\text { g. the dash } \\
\text { a. capitalize the first word in } \\
\text { sentence } \\
\text { b. capitalize pronoun I } \\
\text { c. capitalize the titles of } \\
\text { composition } \\
\text { d. capitalize the proper noun } \\
\text { e. capitalize name of detail, title, } \\
\text { month, day, specific group or } \\
\text { people, geographic areas, and } \\
\text { specific structures. } \\
\text { Avoid misspelling }\end{array}$ \\
\hline 3. Spelling & &
\end{tabular}

From the indicatores above, it lead to the data description and able to answer the research questions. This indicator helps the researcher and the scorers to score the students' test. From those indicators, the researcher can see the students skill through their test and analyze it based on the indicators.

According to Brown (2001) "writing is thinking process, because writing is a process of putting ideas down on paper to transform thought into words and give them structure and coherent organization". In this case, students doing the thinking process through descriptive writing. Descriptive text is a kind of writing that consists of description, characteristics, definition of something, object or something. Descriptive writing also involves putting across feelings, describing place, things and object. In this case the researcher is going to describe the students' skill in writing descriptive text based on their writing test result. 
Figure

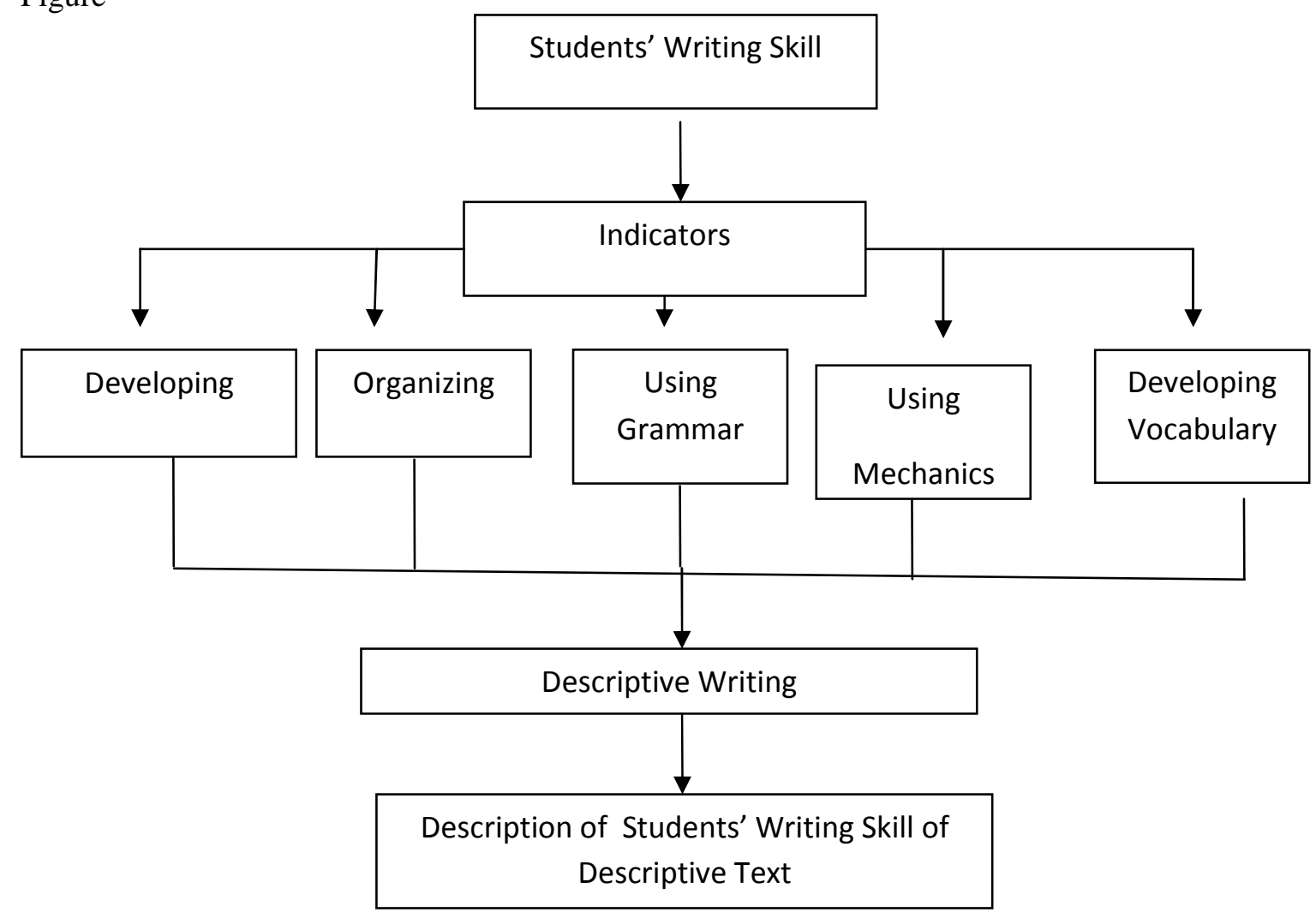

Descriptive text is the text that describes something in order the readers or listener are able to get the same sense as what the writer experienced with his or her six senses: looks, smells, feels, acts, tastes, and sounds. In this case the topic of the writing text is about the place. In writing descriptive text the students have to fulfill the five components of writing, they are developing ideas, organizing ideas, grammar, vocabulary and mechanics.

Developing ideas is the most important thing to the students in writing descriptive text. By developing the ideas, the students can make a good writing text and develop their ideas clearly in each paragraph. In organizing ideas, students have to identify the name of place and describe the detail of the place in the supporting paragraph. In writing descriptive text the students have to use an appropriate grammar, in this case simple present tense. In composing the text, students have to choose the appropriate and accurate words to express the ideas. In mechanics component, students have to use the good punctuation, spelling and capitalization. By analyzing the five components of the students' descriptive text, the researcher can see the students' skill in writing descriptive text.

In the discussion section will discuss the students' result test and their skill in writing the descriptive text. The students' scores in writing descriptive text were presented in the following descriptions 
Table 2

Students' total scores for each component of writing descriptive text

\begin{tabular}{|l|l|l|l|l|l|l|l|l|l|l|l|}
\hline $\begin{array}{l}\text { N } \\
\text { o }\end{array}$ & $\begin{array}{l}\text { Category } \\
\text { Ideas }\end{array}$ & \multicolumn{2}{l|}{$\begin{array}{l}\text { Organizing } \\
\text { Ideas }\end{array}$} & \multicolumn{2}{l|}{ Grammar } & \multicolumn{2}{l|}{ Vocabulary } & \multicolumn{2}{l|}{ Mechanics } \\
\hline 1 & Excellent & & & & & 4 & $14.2 \%$ & & & 3 & $10.7 \%$ \\
\hline 2 & Good & 8 & $28.5 \%$ & 10 & $\begin{array}{l}35.7 \\
\%\end{array}$ & 2 & $7.1 \%$ & 9 & $32.1 \%$ & 2 & $7.1 \%$ \\
\hline 3 & Satisfactory & 13 & $46.4 \%$ & 12 & $\begin{array}{l}42.8 \\
\%\end{array}$ & 21 & $75 \%$ & 15 & $53.5 \%$ & 15 & $53.5 \%$ \\
\hline 4 & Weak & 7 & $25 \%$ & 6 & $\begin{array}{l}21.4 \\
\%\end{array}$ & 1 & $3.5 \%$ & 4 & $14.2 \%$ & 8 & $28.5 \%$ \\
\hline 5 & Poor & 28 & $100 \%$ & 28 & $100 \%$ & 28 & $100 \%$ & 28 & $100 \%$ & 28 & $100 \%$ \\
\hline
\end{tabular}

Table 2 presents the students' scores for each component of descriptive writing. It can be said that none of students get poor score for each component. However, None of the student got excellent for vocabulary, developing ideas, and organizing ideas component. On the other hand there were $10.7 \%$ who students got excellent for Mechanic component and 14,2\% students for grammar component. For good category, there were $35.7 \%$ students who got good for organizing ideas, $28.5 \%$ for developing ideas, $32.1 \%$ for Vocabulary, $7.1 \%$ for Grammar and \& $1 \%$ for mechanics component. For satisfactory category, there were $42.8 \%$ for organizing idea, $46.4 \%$ for developing idea, $53.5 \%$ for vocabulary, 5\% for grammar and $53.5 \%$ for mechanic component. On the other hand, for weak category, there are $21.4 \%$ for organizing idea, $25 \%$ for developing idea, $14.2 \%$ for vocabulary, $3.5 \%$ for grammar and $20.5 \%$ for mechanic component. From the explanation above, it shows the students' scores for each component analyzed in students' descriptive writing. Most of the students got satisfactory for organizing idea, developing idea, vocabulary, grammar and mechanic. It means that the students ability of those four components were satisfactory.

In the second test, the students still composed a descriptive text with the same topic about the place. The students were not allowed to write the same title as the first test. Before the writing activity began, the researcher reminded the student about the component and the theory of writing descriptive text. They were not allowed to take their test home. The researcher provides the time for the writing descriptive text is about 90 minutes and composes a text within 200 words. 
The students' scores in writing descriptive text were presented in the following description.

Table 3

Students score for each component of paragraph

\begin{tabular}{|l|l|l|l|l|l|l|l|l|l|l|l|}
\hline $\begin{array}{l}\mathrm{N} \\
\mathrm{o}\end{array}$ & Category & $\begin{array}{l}\text { Organizing } \\
\text { Ideas }\end{array}$ & $\begin{array}{l}\text { Developing } \\
\text { Ideas }\end{array}$ & \multicolumn{2}{l|}{ Vocabulary } & \multicolumn{2}{l|}{ Grammar } & \multicolumn{2}{l|}{ Mechanics } \\
\hline 1 & Excellent & - & $0.0 \%$ & - & $0.0 \%$ & - & $0.0 \%$ & - & $0.0 \%$ & 2 & $7.1 \%$ \\
\hline 2 & Good & 11 & $\begin{array}{l}39.2 \\
\%\end{array}$ & 12 & 42.8 & 13 & $\begin{array}{l}46.5 \\
\%\end{array}$ & 5 & $17.8 \%$ & 6 & $21.4 \%$ \\
\hline 3 & $\begin{array}{l}\text { Satisfactor } \\
\text { y }\end{array}$ & 9 & $\begin{array}{l}32.1 \\
\%\end{array}$ & 8 & $\begin{array}{l}28.5 \\
\%\end{array}$ & 15 & $\begin{array}{l}53.5 \\
\%\end{array}$ & 16 & $57.1 \%$ & 18 & $64.2 \%$ \\
\hline 4 & Weak & 8 & $\begin{array}{l}28.5 \\
\%\end{array}$ & 8 & $\begin{array}{l}28.5 \\
\%\end{array}$ & - & - & 6 & $21.4 \%$ & 2 & $7.1 \%$ \\
\hline 5 & Poor & - & $0.0 \%$ & - & $0.0 \%$ & - & $0.0 \%$ & - & $0.0 \%$ & - & $0.0 \%$ \\
\hline & & 28 & $\begin{array}{l}100 \\
\%\end{array}$ & 28 & $100 \%$ & 28 & $\begin{array}{l}100 \\
\%\end{array}$ & 28 & $100 \%$ & 28 & $100 \%$ \\
\hline
\end{tabular}

Table 3 present the students' score for each component of the descriptive text. It can be seen that only one of the students got excellent for mechanic component. There are $42.8 \%$ of the students got good score for developing ideas,
$39.2 \%$ students got good for organizing ideas. For vocabulary component there are $46.4 \%$ students got good score and there are $64.2 \%$ of the students got satisfactory for grammar component.

\section{DISCUSSION}

There are five main components in this research that were analyzed to get the category of decriptive text writen by grade XI the students of MAN 2 Padang. They are developing ideas, organizing ideas, grammar, vocabulary and mechanics. These components analyzed according to five categories: Excellent, good, satisfactory, weak and poor.

\section{Developing Ideas}

The topics that were given to the students were considered familiar to the students. However, the research still found some students who unable develop their ideas well. It might be because they do not understand/know how to develop the ideas. The students said that they had studied how to make a good descriptive writing text. But, in practice, they were not success for compose a good writing descriptive text. The first problem is dealing with developing ideas. They confessed that they familiar with the topic, i.e the place. They already wrote the object, but in their writing there were only a small number of ideas presented. They were able to compose a good topic sentence. However, they were unable to develop it into a good paragraph. it also found that some students were not has a paragraph unity, according to Barnet and Stubbs (1990:105) "A good paragraph has unity (it makes one point, or it indicates where one unit of the topic begins and ends)". To have a paragraph unity a student has to support the ideas into the sentences. For example in the first test found some uninformative text. So, the readers were not caught the idea of the writing text. The students admit that this problems due to the difficulties of transforming the ideas from the mind into written text.

\section{Organizing ideas}

Based on the findings, the students faced difficulties in organizing the ideas because they do not know how to deliver it in English. Many of the students failed to organize the text well. It is related to the use of coherence of descriptive writing. They must compose the writing by applying the correct coherences, so the students can bring the real situation to the writing works. 
Reep (2009:82) states that "a paragraph achieves coherence when the sentences proceed in a sequence that supports one point at a time. Transitional, or connecting, words and phrases facilitate coherence by showing the relationship between ideas and by creating a smooth flow of sentences". In organizing the ideas the students have to use two components of generic structure of writing descriptive, they are identification and description.

Gerot and Peter (1994:208) mention that "there are two components in the descriptive text, (1) identification; identifies phenomenon to be described, and (2) description; describes parts, qualities, and characteristics". In identification component, the student has to identify phenomenon to be described. It means that, in description component, the student has to describe parts, qualities and characteristics of the objects. After analyzed the organizing ideas components, it found that there are so many students faced difficulties organized the text well. First, they were able to identify the place. They were able to mention the object, place, the name and the location. However, they can not mention the location only; they have to give the related information about the object. Second, after identify the place the student has to organize it with describe part, qualities and the complete features from the object itself in order to inform the reader. Unfortunately, they were unable to describe the place well. Sometimes, the students cannot organize the paragraph well, seems that they cannot develop the ideas of their writing well. Beside identification and description component, in organizing ideas the students also have to pay attention to the chronological order to their text. Chronological order is order by time; it uses to explain the process, for example where is Yos Sudarso hospital taken place? The students can use: first, second, next, etc to explain about the future of the places. Chronological order also used to describes events period of time. In fact, only small numbers of the students used chronological order. The students confessed that these occurred because they did not write the outline before write the text and did not a list of ideas first. They directly write the ideas coming to their mind. So, it makes their text did not organized well and many repetition of ideas presented.

\section{Vocabulary}

Many of the students have poor choice of words. The ideas of the students are too general. It might be because the students do not know many vocabularies in English, lack of practices and faced difficulties in learning English. Stahl (2005) says that "vocabulary is the knowledge of words and word meanings and also puts vocabulary knowledge as the knowledge of a word not only implies a definition, but also implies how that word fits into the context". Unfortunately, few of students put the words which were unsuitable contextually. It makes the reader should re-read the text in order to comprehend the idea. Even, the students also use some Indonesian language if they did not know how to say the words in English. It means that the students have to enrich their vocabularies. The Students only got the vocabulary input when the teacher explains the material jot down for them.

\section{Grammar}

There are only few mistakes found in grammar component. It might be because the tenses used in the descriptive text are simple sentences which are considered easy for the students.

\section{Mechanics}

Meanwhile, the student did not have difficulties of putting punctuation and capitalization. But sometimes they misspelled because different between the pronunciation and written form of a word. It is reflected in their writing text. They only had a few error mechanics.

\section{METHOD}

This research is descriptive quantitative research. The purpose of the research is to gain information about phenomena in order to describe existed condition in the field. Gay (2005:208) states that "descriptive quantitative research involves collecting numerical data to test hypotheses or answer questions concerning current status conducted either through self-

reports collected through questionnaires or interviews or through observation". Then Gay and Airasian (2000:11) state that "quantitative approaches are used to describe current conditions, investigate relationships, and study cause-effect phenomena". Quantitative descriptive or survey research involves collecting data in order to answer questions about the 
current status of the subject or topic of study and obtain information about preferences, attitudes, practices, concerns or interest of some group of people.

The research was intensed and more detailed into the efforts in the examining about grammar, mechanics, vocabulary and the development of ideas in writing descriptive text. In this study the researcher analyzed the students' difficulties in composing descriptive text. Then the researcher examined the problems that they face. This research contained deep and reaches description and it was more concerned with process than specifying outcome or product. Then the data was analyzed inductively to provide meaning, where the researcher worked to collect data and to find the relevant information and get the conclusion (Syah Nur 2006). This research was conducted at grade XI the students of Madrasah Aliyah Negri 2 Padang. At grade $\mathrm{XI}$, one class consists of 40 students, there were 9 classes which study English in the first year. These 9 classes were handled by three teachers, and each teacher taught three classes.

In this research the researcher used the writing test as the instrument. The topic of the test was about the place, such as House, School, Mosque, Plaza, etc. The topic was chosen by the students about the place that they are interested in. The teachers gave the students 60 minutes to write their descriptive writing text. The words were about 200 words. According to the curriculum, the students expected to write 350 words. From the teacher's information about the

\section{CONCLUSIONS}

Based on findings, it can be concluded that the quality of the students test is satisfactory. The students still have problem in composing the text.

(1) The students were still unable to transfer and develop their idea into a written form well in composing a text.

(2) The students failed to show well-organized writing. They did not use identification and description process on writing appropriately. They not follow the order of writing process. They did not write a list of their ideas; they just directly wrote what they thought without planning.

(3) The students have insufficient vocabularies. They put the words which were unsuitable contextually. students ability in writing descriptive text, they only produced about 200 words. According to Weir (1993:97) e"ach task of each student should be scored independently (as many scores as possible should be involved in the same assessment of each students' work)".

The participans of this research was the second grade students of MAN 2 Padang. They wrote descriptive text in their writing activities. In this case they focused in using the correct grammar, mechanics, vocabulary and develop their ideas into a good text.

The data were collected from the test of the writing of the students at grade XI of MAN 2 Padang randomly. The researcher asked the students to write a descriptive text; she also gave the title of the writing in order to make them easy to express their ideas. The data were collected from the students' writing test by giving enough time, and then the researcher collected the writing.

After getting and collecting the data, the researcher described the students' writing in developing ideas, organizing the ideas, using grammar, using vocabulary and using mechanics of descriptive text wrote by the students at grade XI MAN 2 Padang. Quantitative method was used to analyze the students' writing test. The aspects which were: developing ideas, organizing ideas, grammar, vocabulary and mechanics were scored by the people who competent in scoring the test. The students' tests were scored by people who have good competencies in writing, such as lecturers of English.

(4) The students applied correct grammar, maybe because the grammar for descriptive text is simple present tense. in this case is simple present tense in writing a descriptive text.

(5) Meanwhile, they were able to put mechanics; punctuation, spelling and capitalization in their writing well.

It occurred not only because of the students' failure in following the order of writing process but also because of less effort. They rarely practice writing and a good text in and out classroom. They already know the rules of writing but still unable to apply it. Those problems make their writing skill is still weak. 


\section{BIBLIOGRAPHY}

Barnet, Sylvan and Marcia Stubbs. 1990. Practical Guide to Writing: with Additional Readings $\left(6^{\text {th }}\right.$ ed). New york: Addison Wesley Longman, Inc.

Brown, Douglas. H. 2001. Teaching by Principles. An Interactive Approach to Language Pedagogy. ( $2^{\text {nd }} e d$ ). New York: Addison Wesley Longman, Inc.

Cohen, Andrew D. 1994. Assesing Language Ability in the Classroom: Second Edition. Massachusets: Heinle and Heinle Publisher.

Halliday, 1985. An Introduction to Functional Grammar. London: Arnold.

Harmer,Jeremy. 2002. The Practice of English Language teaching Third Edition Completely Revised and updated. Harlow: Pearson Education Limited.

Harris, David P.1997. Testing English As a Second Language. New York: Mc Grow Hill.

Hogin Burll, james and Yarber Earl, Robert. 1975. Models for Writing Scientific. New York: Research Associates, Inc.

Hogue, Ann. 2003. The Essentials of English: a Writer's Handbook. New York: Pearson Education.

Izmi, Zakwan. 2007. "Solving Students' Problems in Writing Descriptive Essays through Situational Pictures". Unpublished Thesis. Graduate Program: UNP.

Janice, M.laver, et.al. 1981. Four World of Writing. New York: Harper S Row Publisher, Inc.

Knapp, Peter and Megan Watkins. 2005. Genre, Text, Grammar Technologies For Teaching And Assesing Writing. Sydney: University of New South Wales.

Langan, John 2001. English Skills. 7th edition. Singapore. McGraw Hill Education.
Larson, Mildred. 1984. Meaning Based Translation: A guide for the Teacher Researcher. New Jersey: Prentice Hall.

Long, Michael H. and Jack C. Richards (Eds.). 1987. Methodology in TESOL: A Book of Readings.

Boston: Heinle \& Heinle Publishers.

Lynn, Quitman. 1987. Simon and Schuster Handbook for Writers. Englewood Cliff, NewJersey: Prentice Hall, Inc.

Martin, J. 1995. Factual Writing; Explores and Challenging Social Reality. Victoria: Dealing University Press.

Mulyadi. 2008. :An Analysis of Descriptive Texts Written by the Students at SMAN 1 Pagai Utara Selatan Mentawai:. Unpublished Thesis. Padang: Graduate Program: UNP.

Murcia, Mariane Celce (Ed.).1991. Teaching English as a Second Language or Foreign Language $\left(2^{\text {nd }} e d\right)$. New York: Harper Collins Publisher.

Myles, Johanne.2002. "Second Language Writing and Research: The Writing Process and Error Analysis in Students Texts." Teaching English as a Second or Foreign Language. Vol.6,no.2.AI retrieved on Januari $25^{\text {th }} 2009$ )

Nunan, David. 2003. A Practical English Language Teaching. Singapore. McGraw. Hill Education.

Oshima, Alice. 1981. Writing Academic English. New York: Addison Wesley Publishing Company.

Rass, R. Abu. 2001. Integrating reading and Writing for Effective Language Teaching. English Teaching Forum. Vol 10.

Reep, Diana c. 2009. Technical Writing: Principles, Strategies, and Readings. New York: Pearson Education. 
Reid, Joy. 1994. The Process of Paragraph Writing:2nd Edition, New jersey: Prentice hall Regents.

Ruhimul, Indah. 2007. “Teaching Descriptive Texts Using A Process Genre Approach to Improve The Students' Writing Ability. (The Case of the a Year Eighth Students of SMP N Rembang, Purbalingga in the Academic Year 2007/2008)". Unpublished Thesis, Graduate Program in English Language Teaching, State University of Malang.

Stahl, S.A. 2005. Four Problems with Teaching Word Meaning and What to Do to Make Vocabulary an Integral Part of Instruction. Bringing Research to Practice. New Jersey: Prentice Hall Regents.

Swan, Michael. 1983. Practical English Usage. Oxford: Oxford University Press.

Sudarwati, Th.M. and Eudia Grace. 2005. Look Ahead 2: An English Course for Senior
High School Students Year XI. Jakarta: Erlangga.

Syarif, Hermawati and Yetti Zainil. 2008. Modul Bahasa Inggris. Padang: UNP.

Weir, C.J. 1993. Understanding and Developing Language test. New York: Prentice Hall International Ltd.

Wishon, George E. and Julia M. Burks. (1980). Let's Write English. New York: Litton Educational Publishing, Inc.

Wyrick, Jean. 1987. Steps to Writing Well. New York: Rinehart and Winston. Inc.

Zulfariati. 2007. "Types of Grammatical and Punctuation Errors on Students' Final Academic Papers". Unpublished Thesis. Graduate Program: UNP.

Zainil. 2006. Actional Functional Model: Good Language Learner Strategies and Communicative Language Teaching. Padang: UNP press. 